Submission ID: 43880

\title{
The Application of Electrical Prospecting Methods in the Prediction of Traps of Hydrocarbon in Relation to the Conditions of the Western Part of the Siberian Platform
}

E.N. Makhnach* ("Sibgeotech" Ltd), A.V. Mamaeva (Sibgeotech Ltd)

\section{SUMMARY}

The paper described an approach to the joint interpretation of data of electromagnetic (M-ZSB) and magnetotelluric sounding (MTZ) with the aim of highlighting and contouring of hydrocarbon traps in the sedimentary cover of the western part of the Siberian platform saturated with intrusive and tuffogenic formations. Spent network of M-ZSB + MTZ profiles made it possible to highlight and contour the HC trap. The results of the work were confirmed by the subsequent drilling of the Chunkinskaya-282 well. 
Применение методов электроразведки при прогнозировании ловушек углеводородов применительно к условиям западной части Сибирской платформы

Е.Н. Махнач* (ООО ГП «Сибгеотех), А.В. Мамаева (ООО ГП «Сибгеотех)

\section{Введение}

В работе описан подход к совместной интерпретации данных электромагнитных (М-ЗСБ) и магнитотеллурических зондирований (МТ3) с целью выделения и оконтуривания ловушек углеводородов в условиях осадочного чехла западной части Сибирской платформы, насыщенного интрузивными и туфогеннными образованиями. Отработанная сеть профилей МЗСБ+МТЗ позволила выделить и оконтурить ловушку УВ. Результаты работ подтверждены последующим бурением скважины Чункинская-282.

Площадь работ расположена в пределах зоны сочленения Курейской синеклизы и северного склона Бахтинского мегавыступа. В последние десятилетия на исследуемой площади была пройдена сеть регионально-поисковых сейсмических профилей МОГТ-2D и электроразведочные работы комплексом М-ЗСБ+МТЗ. Исследования проводились с целью оценки перспектив нефтегазоносности венд-палеозойского и рифеского комплекса пород, выявления ловушек УВ комбинированного типа.

\section{Методика работ}

Современное представление о применении электромагнитной разведки для прогноза коллекторов в сложных геоэлектрических условиях базируется на всестороннем учете влияния вмещающей среды. Такой подход для условий Восточной Сибири позволяет решать проблемы влияния траппов, очаговой мерзлоты и других неоднородностей перекрывающих целевые объекты осадочного чехла. Методология исследований включает оперирование профильноплощадными данными МТЗ и многоразносными зондированиями М-ЗСБ. МТ3 преимущественно отвечает за изучение глубинных объектов, а М-ЗСБ за регуляризацию решения обратной задачи МТЗ и детальное изучение ВЧР для корректного прогнозирования целевых объектов. Эта методология подкреплена способами обработки данных, базирующихся на высокоточном 3D-моделировании электромагнитных полей, что дает возможность в сложных средах обнаруживать глубинные объекты с откликами, значительно меньшими искажений сигналов от неоднородностей в верхней части.

Методика интерпретации основана на разделении компонент ЭМ-поля поля на нормальную влияния среды, и аномальную - влияния трехмерных неоднородностей. Одновременный подбор объектов и ЭМ-сигналов по всей пространственно-временной области влияния источника позволяет учесть особенности ВЧР, устранить боковые влияния неоднородностей геологической среды не относящихся к поисковым объектам; устраняет искажения реконструкции глубинных частей разреза, резко снижает область эквивалентности решения обратной задачи и повышает достоверность прогноза проводимости и глубины залегания коллектора. Выполнялась в программном комплексе «EM-DataProcessor».

\section{Результаты работ}

Площадь работ расположена в зоне сочленения Курейской синеклизы с северным склоном Бахтинского мегавыступа. Анализ геоэлектрических разрезов позволяет выделить на различных фрагментах профилей до восьми геоэлектрических комплексов пород (рисунок 1).

Первый (p1) высокоомный геоэлектрический горизонт слагают пермско-каменноугольные отложения, вмещающие трапповые интрузии, а также выходы силурийских и девонских отложений. Имеет региональное распространение, хорошо прослеживается на большей части профилей. 
Второй (р2) геоэлектрический комплекс высокопроводящий, имеет повсеместное развитие. Связан с отложениями силура - ордовика. В отложениях ордовика присутствуют проницаемые горизонты в криволуцкой, байкитской, чуньской свитах, которые по показаниям электрического каротажа прогнозируются, как рассолонасыщенные.

Третий (p3) геоэлектрический комплекс проводящий, имеет повсеместное развитие. Связан с терригенно-карбонатными отложениями среднего-верхнего кембрия (эвенкийская свита), представленными мергелем с прослоями доломитов, аргиллитов и алевролитов. Проводимость комплекса формируют локальные зоны трещиноватости в карбонатных отложениях, сформированные в результате внедрения трапповых интрузий, а также наличие глинистого материала.

Четвертый (p4) промежуточный высокоомный геоэлектрический комплекс. Соотносится с соленосно-карбонатной толщей среднего-нижнего кембрия (литвинцевская - усольская свиты). Кровля комплекса картируется по контрастной границе между областями высокого и низкого сопротивления, где переход составляет сотни Ом.м (рис. 1).

Пятый (p5) подсолевой проводящий геоэлектрический комплекс. Соотносится с нижней частью усольской свиты, где проводимость пород обусловлена наличием коллекторов в карбонатном осинским горизонте и в тэтэрской свите венда - нижнего кембрия.

Седьмой геоэлектрический горизонт (p7) - рифейские отложения смешанного терригеннокарбонатного состава. Его проводимость обусловлена наличием глинистого материала в составе рифейских толщ, а также трещинно-кавернозных коллекторов в карбонатах. По данным электроразведки, в кровле рифейских отложений прогнозируется наличие отложений с улучшенными коллекторскими свойствами.

Восьмой геоэлектрический горизонт (p8) - рифейские отложения карбонатного состава.

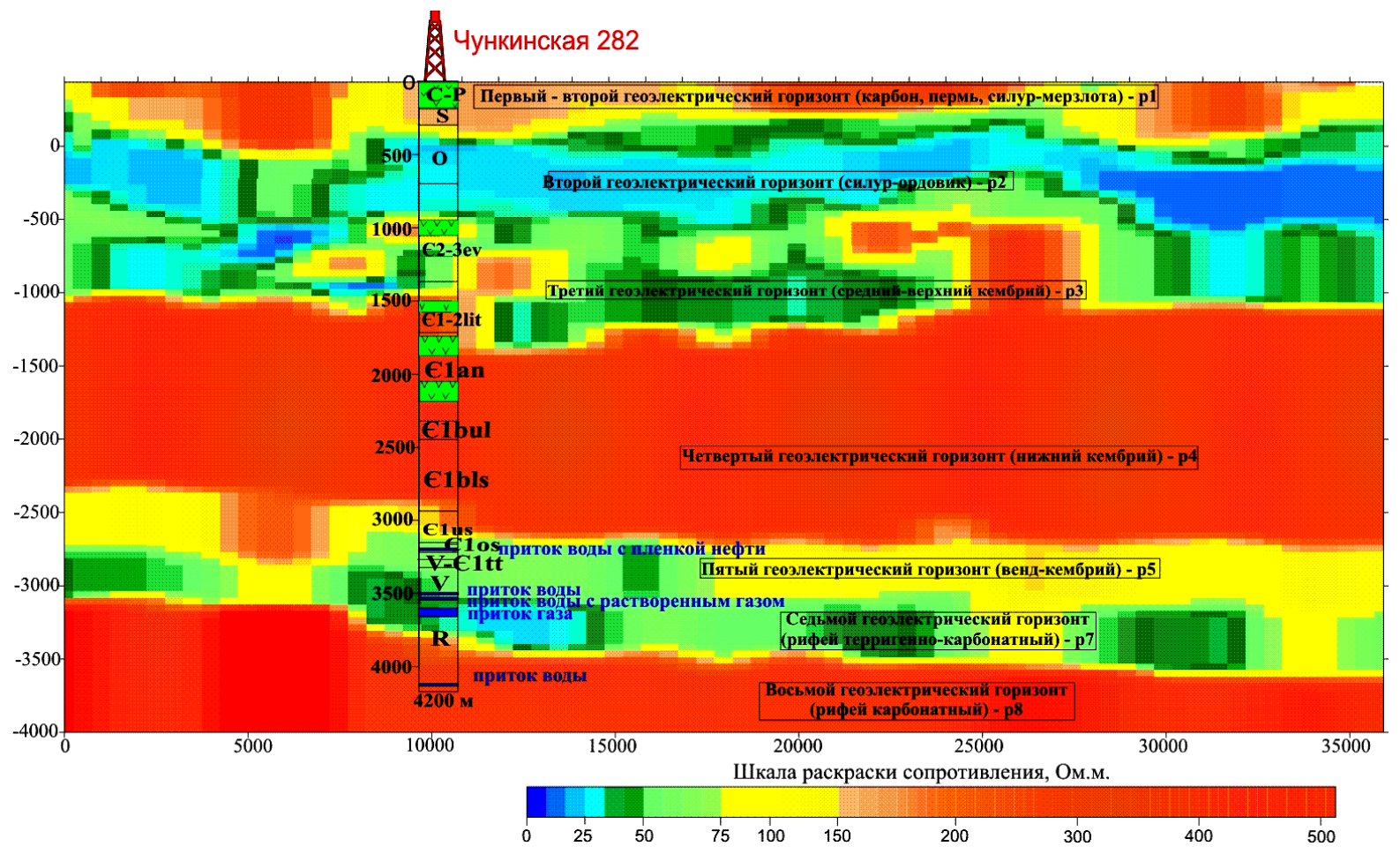

Рисунок 1 Геоэлектрический разрез до глубины 4000 м

По данным электроразведки на площади выполнена оценка перспективности рифейского, вендского и нижнекембрийского НГК (по структурным, тектоническим, стратиграфическим и литологическим признакам). Перспективность рифейского и вендского комплексов связывается с выклиниванием отложений к бортам прогиба. В зонах их прилегания к выступам фундамента закартирована зона аномальной проводимости, с которыми связываются перспективы обнаружения ловушек УВ (рисунок 2). Стратиграфические уровни залежей кровля рифея - терригенно-карбонатный венд. Прогнозируемый тип коллекторов трещинно- 


\section{EAGE}

кавернового типа, коэффициент пористости пород (оценивался качественно и количественно по известной формуле Дахнова-Арчи) составляет около 10 - 15\% и характеризует их как хорошо проницаемые. Глубина залегания продуктивных горизонтов - $3700-4000$ м. Конфигурация ловушки в районе скв. Чнк-282 в плане показана на рисунке 2. Место расположения скважины находится в левой краевой части аномалии проводимости, где значения параметра составляют около 20 См, а увеличение проводимости разреза прогнозируется на север от скважины. К краевым частям ловушки приурочены геохимические аномалии.

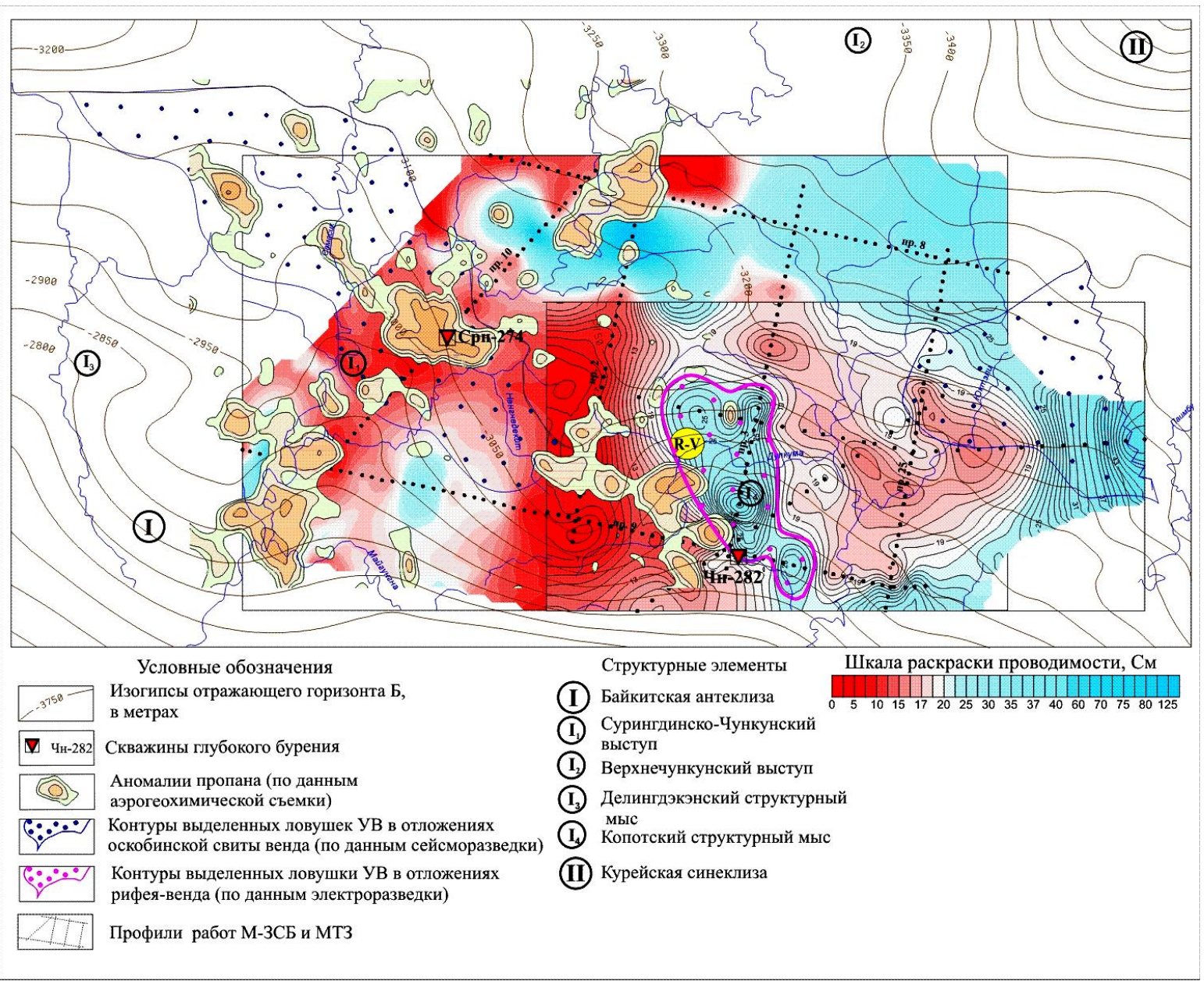

Рисунок 2 Выделение ловушки УВ по данным электроразведки

По данным последующего бурения и испытания скв. Чункинская 282 получены притоки пластовой воды с сероводородным газом и тонкой пленкой нефти из осинского горизонта, приток пластовой воды с растворенным углеводородным газом из отложений венда, приток пластовой воды и углеводородного газа из отложений рифея. Полученные данные характеризуют расположение скважины в краевой части ловушки, а основная залежь прогнозируется в юго-восточном и, ограниченно, в северном направлении.

\section{Выводы}

Основные геологические задачи, которые ставились перед электроразведкой - это изучение геоэлектрического разреза осадочного чехла и фундамента, выделение зон повышенной проводимости, связанных с улучшенными коллекторскими свойствами отложений, оконтуривание ловушек УВ успешно решены. В условиях сложного строения ВЧР (наличие трапповых интрузий, туфогенных пород, мерзлоты, отложений, обладающих аномальновысокой проводимостью) решение этих задач достигнуто за счет комплексирования методов 
М-3СБ и МТ3 и последующей 3D-интерпретацией данных. Полученные результаты заверены бурением. Сделан вывод, что при проведении нефтегазопоисковых исследований в обязательный комплекс работ необходимо включать электромагнитные многоразносные зондирования (М-ЗСБ) и магнитотеллурические зондирования (МТЗ). При невысокой стоимости работ (относительно сейсморазведки) применение электроразведки позволяет существенно снизить риски непродуктивного бурения и оптимизировать процесс ведения ГРР.

\section{Библиография}

1. Соловейчик Ю. Г., Рояк М.Э., Моисеев В.С., Тригубович Г.М. Моделирование нестационарных электромагнитных полей в трехмерных средах методом конечных элементов // Физика Земли. - 1998. - № 10. - С. 78-84.

2. Тригубович Г.М., Персова М.Г., Соловейчик Ю.Г. «ЗD-электроразведка становлением поля» // Новосибирск: Наука, 2009. - С. 214.

3. Мельников Н.В. Венд-кембрийский соленосный бассейн Сибирской платформы (Сратиграфия, история развития). Новосибирск. СО РАН, 2009., 148 с +3 цв. вкл.

4. Перспективные на нефть зоны и объекты Сибирской платформы: Сб. науч. тр./ под ред. В.С. Старосельцева. Новосибирск: СНИИГГиМС, 2009., 99с.

5. Эпов М.И., Поспеева Е.В., Витте Л.В., Геология и геофизика, 2012, т. 53, № 3, с. 380-398 Особенности состава и строения земной коры краевой части Сибирского кратона (в зоне влияния рифтогенных процессов) по данным магнитотеллурических процессов.

\section{References}

1. Solovejchik U.G., Royak M.E., Moiseev V.S., Trigubovich G.M. The modeling of non-stationary electromagnetic fields in three-dimensional media by the finite element method // Physics Of The Earth. - 1998. - № 10. - p. 78-84.

2. Trigubovich G.M., Persova M.G., Solovejchik U.G. «3D electrical exploration of the field formation» // Novosibirsk: Science, 2009. - p. 214.

3. Melnikov N.V. The Wend-Cambrian salt basin of the Siberian platform (Sratigraphy, development history). Novosibirsk. SO RAN, 2009, 148 p.+3 color tabs.

4. Promising oil zones and objects of the Siberian platform. Under the editorship of V.S. Staroselceva. Novosibirsk: SNIIGGiMS, 2009, 99 p.

5. Epov M.I., Pospeeva E.V., Vitte L.V. Geology and Geophysics, 2012, vol. 53, № 3, p. 380-398 The features of composition and structure of the crust the outer part of the Siberian craton (in the zone of influence of rifting processes) according to magnetotelluric processes. 